\title{
THE UTILIZATION OF INFORMATION TECHNOLOGY AS LEARNING MEDIA
}

\author{
Fitrani Dinda Fadhilah ${ }^{1}$ \\ Fitri Handayani Harahap ${ }^{2}$ \\ Nur Zarit Sofia ${ }^{3}$ \\ Suhendri Prayoga ${ }^{4 *}$ \\ Muhammad Taufik Ihsan ${ }^{5}$
}

1,2,3,4,5 State Islamic University of Sultan Syarif Kasim Riau, Indonesia

11910421261@students.uin-suska.ac.id ${ }^{1)}$

11910423601@students.uin-suska.ac.id $\left.{ }^{2}\right)$

11910423003@students.uin-suska.ac.id ${ }^{3)}$

11910413292@students.uin-suska.ac.id $\left.{ }^{4 *}\right)$

muuhammad.taufik.ihsan@uin.suska.ac.id ${ }^{5)}$

\begin{abstract}
The development of information and communication technology build it straightforward to speak in exchanging information in order that place, time and distance are not any longer obstacles. Moreover, through the internet data services are often accessed as learning resources within the world of education should be ready to follow the event of technological science. Therefore the use of technology within the style of learning media may be an alternate to beat the constraints of house and time of the prevailing learning method so lecturers don't got to make a case for the fabric to students in excess. In this article, the data were obtained from literature of study review and from other document analysis. Based on the study, The Utilization of information and communication technology in learning is carried out in order to increase effectiveness in the implementation of the learning process to improve student learning outcomes and the individual quality of students in terms of using technology more precisely and usefully.
\end{abstract}

Keywords: Education, Information Technology

Published by:

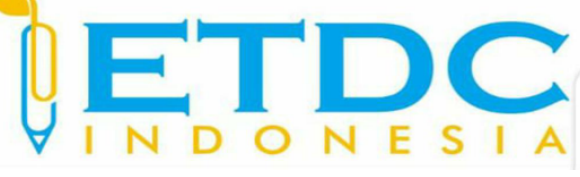

Copyright (C) 2021 The Author (s)

This article is licensed under CC BY 4.0 License

$(\mathrm{cc}) \mathrm{EY}$ 


\section{THE UTILIZATION OF INFORMATION TECHNOLOGY AS LEARNING MEDIA}

\section{Introduction}

Information technology that is currently developing is used in almost all aspects of life. One aspect that cannot be separated from the use of information technology is education. In the world of education, information technology is used as part of the learning media to present subject matter to make it more interesting, not monotonous, and to facilitate the delivery of learning materials.

Learning is a complex process that occurs in everyone throughout his life. The learning process occurs because of the interaction between a person and his environment. One sign that someone is learning is a change in the person's behavior which may be caused by changes at the cognitive, psychomotor and affective levels.

Degeng (2004) saw the quality of learning from two aspects: the process and the result of learning. While efforts to improve the quality of the learning process lead to initiative from students and educators. As degeng (2004) states, miarso (2004) said factors that either influence or support the realization of the quality learning process in efforts to achieve education goals, one is the use of information technology and communication in the learning process. Ict in its learning is known as educational technology, UNESCO formally uses the term ict that is then adopted into Indonesian into information and communication technology or ICT (Husain, 2014).

According to the abdulhak (2005) there are classification of ICT use, namely: first, ICT as an educational medium (tool) that only serves to clarify the explanation presented. Second, ICT as a source, that is, as a source for information and information finding. And third, ICT as a learning system.

The pioneer of teaching and learning software provider in Indonesia is Pustekkom of the Ministry of National Education. The IT program from Pustekkom is a computer-based learning media. This media combines and synergizes all media consisting of text, graphics, photos, videos, animations, music, narration, and interactivity programmed based on learning theory.

Applications of technology-based learning media are the use of hardware technology (hardware) and the use of software (software) for presentations, showing moving pictures (videos), audio (audio) as a learning medium. Changes in learning patterns are needed to make changes in traditional learning systems that are viewed as quaint and irrelevant to the fast- 
growing, intensified dynamics of the age. Information technology and communication in learning act as links in the implementation of knowledge transfer without completely eliminating the initial direct learning model in class.

The use of information technology and communication in learning is done to improve the effectiveness of the application of media that is expected to improve the students' learning results and the individual qualities of students in their more appropriate and useful use of technology.

\section{Methodology}

This journal was created using document and article analysis. We'll start with a definition of information technology. First we'll also go over the definition of information technology, which will analyze through some articles and journals. The second is about the role of information technology and computers as learning media, and the third is about an example of learning media that using information technology system. And finally is about a plan for employing information technology as a learning tool. All of the materials in this research were found through a variety of papers, books, and internet sources. This study will help students choose and use technology for learning media, which will be especially useful amid the current covid-19 epidemic.

\section{Discussion}

\section{a. Definition of Information Technology}

Information technology (IT) was used as a catch-all term for communication and computing tools, whereas educational MK technology denoted the use of IT tools in teaching and learning. The concept that information technology can contribute to the optimization of corporate resources, as well as strengthening, enabling, and improving business and educational performance, has been accepted and supported by various empirical.

The term "information technology" itself refers to the process of knowledge and its methods for processing, transferring, and creating information in progress. IT means that information is collected, organized, stored, published, used by computer use and the use of toll telecommunications, sound, image graphics, text, numbers, etc.One of the roles of education information systems is to make sure that we offer the information that is essential when needed. We must evolve to predict the information we need to access it if necessary. In some forecasts IT ends in a 'global village,' and in others new information technologies are supported 
by international understanding, peace and fellowship.

Others regard technology as a factor in increasing self-reliance and promoting democracy. Others have regarded technology as a factor liberating third-world masses, so, in their view, getting information through larger communication systems as a goal must be followed. But developing it, in addition to hard access to technology, is dealing with structural and behavioral problems associated with it. Efficiency in these systems depends on software's political, cultural, technical and economic factors, and the quality of the institutionalization of software and its application.Many school districts discovered that allowing students to bring their own devices to school was more cost effective (Kiger \&Herro, 2015). Studies show that learners use their own electronic devices to be more efficient and confident(Riedel, 2014).

\section{b. The Role of Information Technology and Computers as Learning Media}

In general, the media is defined as a communication tool that carries messages from the source to the recipient. This understanding leads to a more specific understanding of media. More broadly it is said that the media is a message-laden tool, which allows people or students to be oriented directly to the message. This technology media is a media specifically designed to achieve certain learning objectives, such as offline and online-based Information and Communication Technology (ICT) (Situmorang, 2013)

Utilization of presentation media can be used by educators and students to present learning materials and assignments that have been given. Through the use of media presentations, teachers and students will be more helpful in terms of time, this is because the teacher no longer needs to write on the blackboard about the discussion of the material being delivered while students can also use more time to communicate, discuss, or ask the teacher .

With the technological capabilities possessed, the "computer" becomes a very effective and efficient means to be used as a modality in learning. This is what makes computer technology provide a lot of variety in learning, especially when the technology becomes a medium that is connected to the internet.

Computers were used in the classroom to teach the basic skills and provide the knowledge of computer as per the curriculum. For example, word processor was used to improve the writing skills of the students.

Broadly, one can consider the following roles of education where computer has been effectively used as shown on the graphic below. 


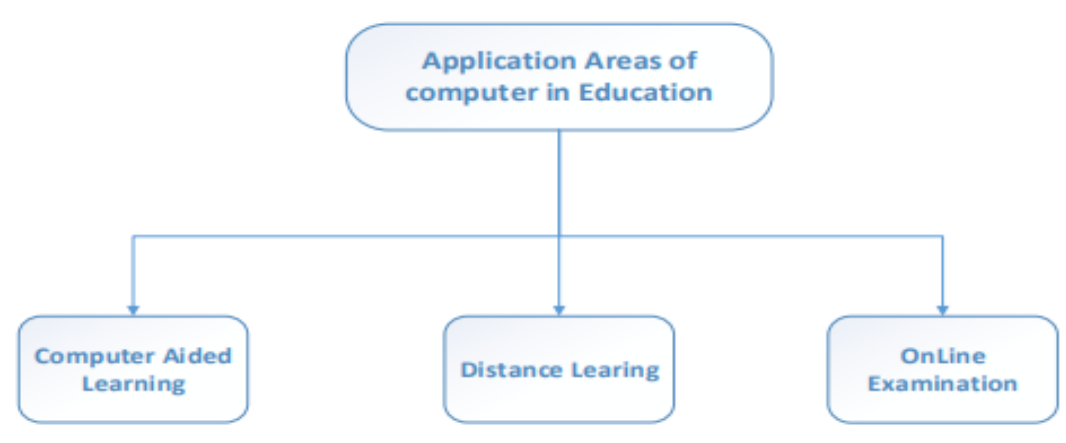

Figure 1. Computer Application Area

\section{Distance Learning}

Computer and technologies have been used in distance learning through various ways such as Teleconferencing, video-conferencing, audio graphics, Teletext, video text, multimedia and hypermedia, ebooks, online database, online discussion, on-demand call in course etc. Virtual classrooms play an important role in distance learning.

\section{On-Line examination and monitoring}

Online examination and monitoring system have completely changed due to the development of modern education technology. These systems ensure about the fairness and impartiality in the examination.

\section{Computer-Aided Learning}

Computers have improved the quality of teaching and enhance the learning process with the help of various tools such as multimedia projector, PowerPointpresentations etc. Information technology make learning process more interested through games, animated graphics etc (Dabas, 2018)

The use of computers in mathematics also has many uses, both as a calculating tool and as a means of delivering subject matter. As a calculating tool, the computer can perform calculations to find: logarithms, trigonometric comparisons, arithmetic operations, and so on. In mathematics learning, computers are widely used to convey material that requires motion (animation), images, text, and colors. All these facilities are on the computer and all these facilities can be used to visualize abstract concepts in mathematics into concrete. However, although the use of computers can improve student achievement, computers cannot replace the role of the teacher as a whole.

The presence of ICT as a learning medium helps teachers (educators) in various ways, including:

1. Learning becomes more interesting and interactive

The use of learning media in the form of photos or videos can attract students' attention 
when compared to oral descriptions. Teachers can create a variety of varied activities and activate students through photos or pictures of the objects discussed.

2. Learning becomes more concrete and real.

The use of learning media at the elementary school level, especially in the lower grades, is in accordance with the characteristics of students who are still in the "concrete-operational" level. With this media, students will find it easier to learn everything that they can directly see, hear, hold and feel.

3. Learning management is more effective and efficient

With learning media, teachers can be helped not to need a lot of writing or illustrating on the blackboard. The illustrations and writings required by the teacher can be fulfilled by the teacher in a timely and fast manner through the pliers available on the computer.

4. Encourage students to learn more independently.

Learning media that have been specifically designed for certain learning can be used by students to learn both individually and in groups.

5. Improving the quality of learning.

With learning media, the learning process becomes more effective and efficient, and can improve the overall quality of learning.

6. The learning process can be done anywhere and anytime

Audio, video, computer programs (offline and online) are learning media that can be used anywhere and anytime according to the conditions and situations of teachers and students.

7. Generating a positive attitude of students towards the learning process.

The use of media designed according to student learning needs can lead to positive attitudes of students towards the teaching and learning process.

\section{c. The example of learning media that using information technology system}

In recent years, classroom technology has grown more inexpensive and accessible. Many governments are taking steps to improve student access to technology and provide additional technology training for instructors. When students are actively engaged with technology, they are more likely to learn independently.

Various tools and avenues are developed with the goal of more effectively delivering training and learning to learners. There are several examples of educational technology that provide individuals with information, therefore making them knowledgeable. The technology strategy for schools includes tools that facilitate learning and assist instructors in understanding any issues that may influence their students.

Schools can utilize it on their students in a variety of ways. It may be utilized in the 
classroom as well as online. The goals of educational technology are to offer training in the use of ICT, to influence learning experiences in educational institutions, and to participate in computer-based instructional materials.

Students can also teach one another when they use technology to learn. While there are many ways to incorporate technology into the classroom, here are a few that are becoming increasingly popular. Over the next decade, teachers are expected to utilize them more and more.

\section{Interactive Whiteboards}

An interactive whiteboard, sometimes known as an interactive touchscreen, is a display that is connected to a computer and a projector. Its dimensions are generally comparable to those of a standard white board. A finger or a pen may be used to operate the computer directly on the board's surface. Accessories such as student response systems may be included with interactive whiteboards. It's important to remember to speed up the information while utilizing such a complex tool so that students have enough time to analyze what's being presented to them.

\section{Virtual Reality Headsets}

Virtual reality goggles can be used in conjunction with specific apps by students. Students' emotional responses to virtual reality can be generated, which can improve empathy as well as learning. Experts believe that virtual reality will alter the role of education from information transmission to content facilitation. Through a range of VR activities, such as virtual field trips and art and scientific studies, students engage with fresh learning rather than being given static content.

\section{D Printing}

Students may use 3D printing in the classroom to learn about art, history, math, and science, as well as critical thinking. 3D-printed items also provide great study tools, making some concepts more accessible and simpler to visualize than $2 \mathrm{D}$ ones. Both visual and non-visual learners can benefit from 3D printing to better comprehend new topics.

\section{Podcasts}

Listening to podcasts is a low-key usage of technology when contrasted to interactive whiteboards, virtual reality headsets, and 3D printers, but it may still be an effective method to educate. Podcasts may be a great method to enhance courses. Listening to interviews with authors can help students study effectively. It promotes auditory learning as well. Writing and recording their own podcasts is a fun method for kids to practice writing and speaking skills. 


\section{d. The Strategy to implement an information Technology as learning media}

The application of learning media in teaching and learning activities is very important to be planned and designed properly and systematically, this is so that the learning media can be effective to be applied in teaching and learning activities in education.

There are several strategies for implementing learning media, namely:

1. Utilization of media in classroom situations or in the classroom.

Learning media are used to support the achievement of certain goals and their use is combined with the teaching and learning process in classroom situations.

2. The use of media outside the classroom situation or outside the classroom, including:

- Free use, namely the media used is not required to be used by certain users and there is no control and supervision from the media maker or manager, and users are not managed with certain procedures and patterns

- Controlled utilization is that the media is used in a series of activities that are systematically arranged to achieve the learning objectives that have been determined to be used by certain target users (target population) by following certain learning patterns and procedures until they can achieve these learning objectives.

3. The use of media individually, in groups or in mass, includes:

- Individual use of media, namely the use of media by only one person (alone)

- Utilization of media in groups, both small groups (2-8 people) and large groups (9-40 people).

4. Media can also be used in massive.

It's mean that media can be used by tens, hundreds or even thousands of people using the same media together.

\section{Conclusion}

The concept that information technology can contribute to the optimization of corporate resources, as well as strengthening, enabling, and improving business and educational performance, has been accepted and supported by various empirical studies. In some estimates IT ends up in 'global villages,' and in others new information technologies are supported by international understanding, peace and alliance.

Others regard technology as a factor in increasing self-reliance and promoting democracy.Others have regarded technology as a factor liberating third-world masses, so, in 
their view, getting information through larger communication systems as a goal must be followed.With the technological capabilities possessed, the «computer» becomes a very effective and efficient means to be used as a modality in learning. This is what makes computer technology provide a lot of variety in learning, especially when the technology becomes a medium that is connected to the internet.

Computers are used in the classroom to teach basic skills and provide computer knowledge according to the curriculum. For example, word processors are used to improve students' writing skills. Its technology has proven to be very successful in educational management applications such as planning, data analysis etc. According to Li. The use of computers in mathematics also has many uses, both as a calculating tool and as a means of delivering subject matter.

In learning, computers are widely used to convey material that requires motion, images, text, and colors. All these facilities are on the computer and all these facilities can be used to visualize abstract concepts in mathematics into concrete. However, although the use of computers can improve student achievement, computers cannot replace the role of the teacher as a whole. It's mean that media can be used by tens, hundreds or even thousands of people using the same media together.

\section{REFRENCES}

Anshori, Shodiq. Pemanfaatan Teknolog iInformasi Dan Komunikasi Sebagai Media Pembelajaran_. Civic-Culture: Jurnal Ilmu Pendidikan PKN dan Sosial Budaya. ISSN 2579-9878.

Abdulhak, H. I. \&Sanjaya, W. (2005). Media Pendidikan: Suatu Pengantar. Bandung: Pusat Pelayanan dan Pengembangan Media Pendidikan UPI Bandung.

Biasi, V., \& Domenici, G. (2014). Motivational Processes in Online Learning: The Role of Tutorship for Laboratory Activities through the Semi structured Self-Evaluation Tests. Education Research International, 2014.

Chaidar Husain, (2014) Utilization of Information and Communication Technology in Learning at SMA Muhammadiyah Tarakan, Journal of Educational Policy and Development, Volume 2, Number 2, July 2014.

Cheung, A. C., \& Slavin, R. E. (2013). The effectiveness of educational technology applications for enhancing mathematics achievement in K-12classrooms: A meta-analysis. Educational Research Review.

Dabas, Dr. Neetu. 2018. _Role of Computer and Information Technology in Education System_. International Journal of Engineering and Techniques. Volume 4 Issue 1. 
Forzani. Rohani., Ahmad. (2014) "Utilization of Information and Communication Technologies in Mathematics Learning”. Selangor. Darul Ehsan, Malaysia.

Husain, chaidar. 2014. _Pemanfaatan Teknologi Informasi dan Komunikasi dalam Pembelajaran di SMA Muhammadiyah Tarakan. Jurnal Kebijakan dan Pengembangan Pendidikan, Volume 2, No. 2.

Situmorang, Robinson. 2013. Pembelajaran Berbasis Teknologi Informasi dan komunikasi. Jakarta:Kencana Prenada Media Group.

Zayyadi, Moh. dkk. 2017. Pemanfaatan Teknologi Komputer Sebagai Media Pembelajaran Pada Guru Matematika. Volume 1. No 2. 